\title{
Open-Source Electrochemical Measurement System Equipped with Macro Language for Successive Measurements
}

\author{
Hidenobu SHIROISHI ${ }^{a}$ and Tatsuhiro OKADA ${ }^{\mathrm{b}}$ \\ ${ }^{a}$ Research Institute for Green Technology, \\ National Institute of Advanced Industrial Science and Technology (NEDO fellow) \\ Higashi 1-1-1, Tsukuba, Ibaraki 305-8565, Japan \\ ${ }^{\mathrm{b}}$ Research Institute for Green Technology, National Institute of Advanced Industrial Science and Technology \\ Higashi 1-1-1, Tsukuba, Ibaraki 305-8565, Japan \\ *e-mail: cpx26485@mopera.ne.jp
}

(Received: December 9, 2003; Accepted for publication: January 29, 2004; Published on Web: April 27, 2004)

\begin{abstract}
An open-source electrochemical measurement system called ECHAN (ElectroCHemical ANalyzer) has been developed with Visual Basic Language. This software enables automated measurement of electrode samples with macro language successively through various electrochemical methods. Cyclic voltammetry, rotating ring-disk voltammetry, potential step chronoamperometry, current vs. rotation speed measurement and multipotentiostat measurement are all carried out with this single software. It is also equipped with a searching function by keywords and measurement conditions. After measurement, data can be processed by FFT (Fast Fourier Transform) low pass filter, smoothing by the simple moving average or the Savitzky-Golay method and operations between two data sets. It makes possible the evaluation of electro-catalysis by the Koutecky-Levich analysis, the Levich analysis, the electron number concerned with oxygen reduction reaction, chronoamperometry analysis by Cottrell's equation, coulomb number calculation and the Tafel analysis. Since an A/D board is used for data sampling, this program is applicable to a conventional potentiostat, which is usually connected to an $\mathrm{X}-\mathrm{Y}$ recorder.
\end{abstract}

Keywords: Electrochemical measurement system, ECHAN, Successive measurements, Open source, Oxygen reduction, Screening of electro-catalysts

\section{Introduction}

The screening of new catalysts or probes is indispensable for improvement or development of devices such as chemical sensors [1-3], electrosynthesis [4, 5] and fuel cells [6-8]. A developer evaluates the performance of numerous materials routinely but facing complexity of measurements. For example, a researcher assesses the catalytic activity of materials by cyclic voltammetry and linear sweep voltammetry either hydrodynamically or hydrostatically, and analyzes the obtained data by the Koutecky-Levich equation and the Tafel equation. If such measurements and analyses are automated by a program, the screening of catalysts will be performed efficiently. There are some automation software packages not for conventional electrochemical equipment only connectable to an X-Y recorder but for a specific expensive electrochemical apparatus.

Useful information is often obtained from the combination between an electrochemical measurement and another measurement such as spectrometry carried out simultaneously. In such a situation, a specific program must be developed each time when a new system is installed. If an open-source program for electrochemical measurements were provided, a program serving the purpose might be obtained by a little modification of the existing software. In this study, we report an open-source software called "ECHAN" (ElectroCHemical ANalyzer) for automatic electrochemical measurements and analyses, which runs on Windows 98/Me/2000/XP. The program is written in Visual Basic Ver. 6, and its source code consists of 42 modules (about 10,000 lines). 


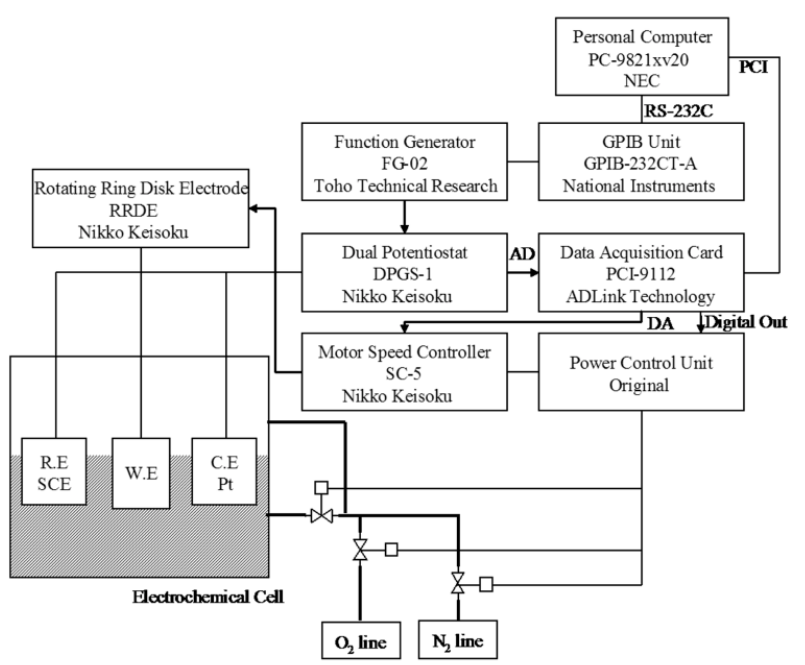

Figure 1. Wiring diagram of the electrochemical equipment.

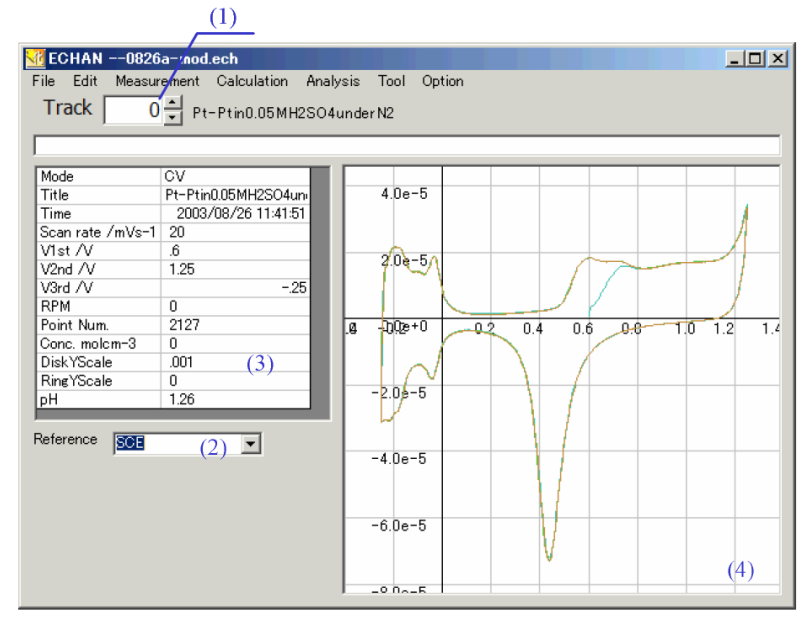

Figure 2. Screen shot of the control panel of "ECHAN". (1) Present track and "Updown button" for selecting a track. (2) "Combo box" for the conversion between reference potentials (3) Information table for the present track. (4) Graph area of the present track.

combo box (Figure 2 (2)). The user can change a title, current scales and $\mathrm{pH}$ by clicking the item of an information area (Figure $2(3)$ ).

Table 1 shows the commands of ECHAN allocated to the menu bar. Since many functions are equipped in this software, some of the menus are described below as examples. The details of the usage are written in a help file.

\section{1) File menu}

An original text file format ".ech" is used in "ECHAN". Figure 3 shows the screen shot of a form module for searching tracks. The user can search data sets by keywords and measurement conditions in a specific folder.

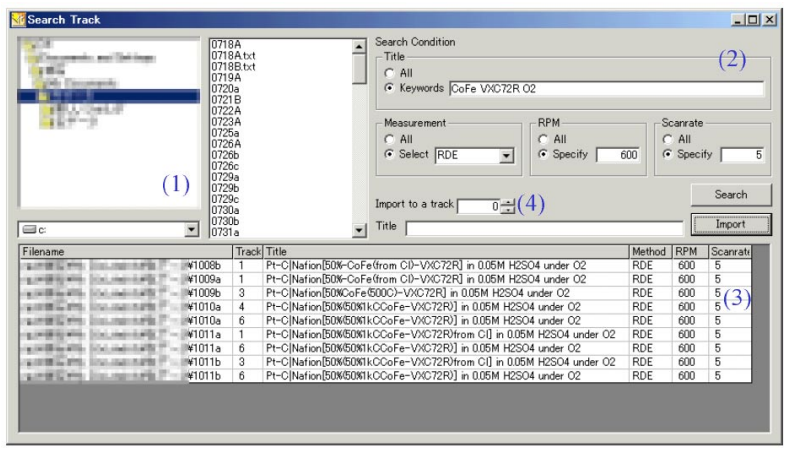

Figure 3. Form module for searching data sets by keywords and measurement conditions. (1) "Directory list box" and "Drive list box" for specifying a folder. (2) Dialogue area for search conditions (3) Result table matched to the condition (4) "Updown button" for a destination track. 
Table 1. Command in ECHAN.

\begin{tabular}{|c|c|c|}
\hline & Menu/Submenu & Description \\
\hline \multicolumn{3}{|l|}{ File } \\
\hline & Open & Open experimental data sets in ECHAN format. \\
\hline & Save as & Save experimental data sets in ECHAN format. \\
\hline & Import Track & Import an experimental data set from another file. \\
\hline & Search Track & $\begin{array}{l}\text { Search experimental data sets by keywords and measure- } \\
\text { ment condition. }\end{array}$ \\
\hline & Quit & Quit ECHAN \\
\hline \multicolumn{3}{|l|}{ Edit } \\
\hline & Copy All as Text Data & $\begin{array}{l}\text { Copy an experimental data set and its information to clip- } \\
\text { board. }\end{array}$ \\
\hline & Copy I-E (or t) as Text Data & Copy an experimental data set to clipboard. \\
\hline & Replace Words in each title & Replace words in each title \\
\hline & Special Copy & Copy an optimized experimental data set to clipboard. \\
\hline & Edit Tracks & Copy or Move an experimental data set to another track. \\
\hline & Edit a Track & Edit an experimental data set. \\
\hline & Delete a Track & Delete an experimental data set. \\
\hline & Paste from Clipboard & $\begin{array}{l}\text { Paste to the present track from clipboard (tab separated } \\
\text { values only). }\end{array}$ \\
\hline & Copy I-t Table (Multipotentiostat Only) & $\begin{array}{l}\text { Copy current-timeable measured by multipotentiostat } \\
\text { mode to clipboard. }\end{array}$ \\
\hline & Copy V-I Table (Multipotentiostat Only) & $\begin{array}{l}\text { Copy voltage-current table measured by multipotentiostat } \\
\text { mode to clipboard. }\end{array}$ \\
\hline \multicolumn{3}{|l|}{ Measurement } \\
\hline & Cyclic Voltammogram & $\begin{array}{l}\text { Measure a cyclic voltammogram under hydrostatic or hy- } \\
\text { dromic condition. }\end{array}$ \\
\hline & RDE & $\begin{array}{l}\text { Measure a rotating ring-disk voltammogram under hy- } \\
\text { drostatic or hydrodynamic condition. }\end{array}$ \\
\hline & Potential Step & $\begin{array}{l}\text { Measure a potential step measurement under hydrostatic } \\
\text { or hydrodynamic condition. }\end{array}$ \\
\hline & RPM vs. I & $\begin{array}{l}\text { Measure a rotating-speed sweep measurement under hy- } \\
\text { drodynamic condition. }\end{array}$ \\
\hline & Multipotentiostat & Measure time, current and voltage with multipotentiostat. \\
\hline \multicolumn{3}{|l|}{ Calculation } \\
\hline & FFT Filter & Smooth an experimental data set by FFT low pass filter. \\
\hline & Smoothing & $\begin{array}{l}\text { Smooth an experimental data set by the simple moving } \\
\text { average or the Savizky-Golay method. }\end{array}$ \\
\hline & Calculation & Calculate between two tracks. \\
\hline \multicolumn{3}{|l|}{ Analysis } \\
\hline & Koutecky-Levich Analysis & $\begin{array}{l}\text { Analyze a data set based on Koutecky-Levich or Levich } \\
\text { equation }\end{array}$ \\
\hline & $\% \mathrm{H}_{2} \mathrm{O}$ Analysis & $\begin{array}{l}\text { Calculate percentages of } 4 \text {-electron reduction in total } \\
\text { oxygen reduction reaction }\end{array}$ \\
\hline & Cottrell Equation Analysis & Analyze a data set based on Cottrell equation \\
\hline & Coulomb Number Calculation & Calculate Coulomb number in desired range of a data set. \\
\hline & Tafel Analysis & Analyze a data set on the basis of Tafel plot \\
\hline \multicolumn{3}{|r|}{$x^{2}$} \\
\hline & Power Control & Show a power control module \\
\hline & Macro & Show a macro editor for automatic measurement \\
\hline \multicolumn{3}{|r|}{ ( } \\
\hline & Settings & Show settings \\
\hline
\end{tabular}




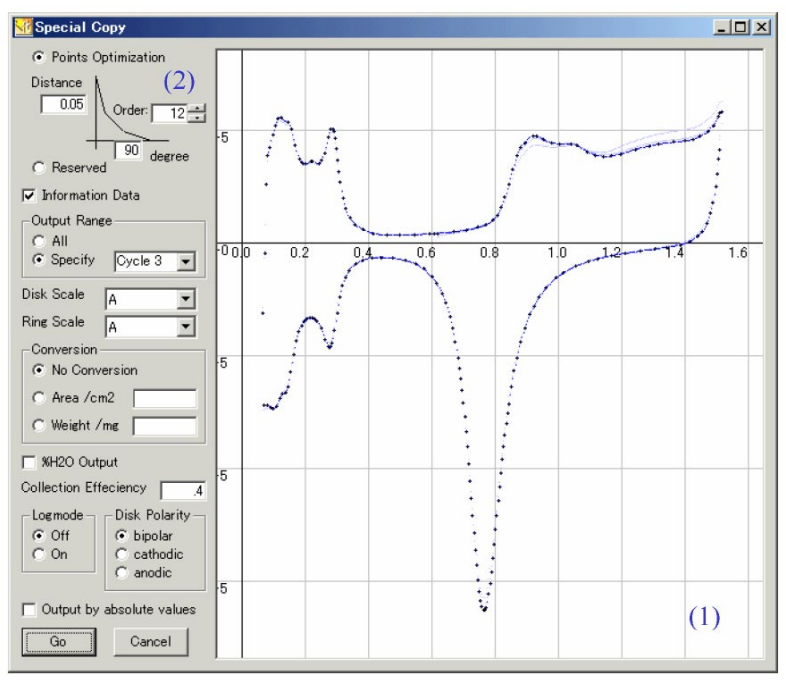

Figure 4. Screen shot of "Special Copy" form module. (1) Preview window for native data (blue dots) and reduced data (black dots). (2) Dialogue for specifying parameters.

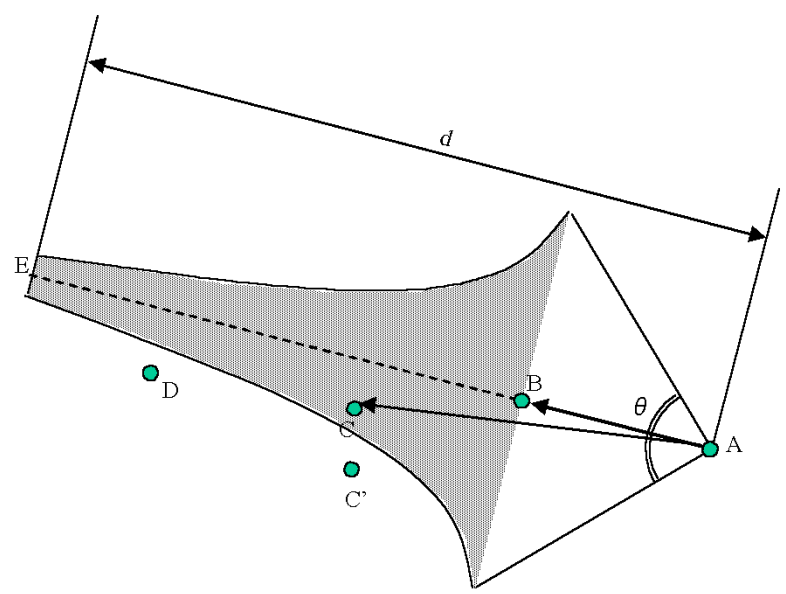

Figure 5. Illustration for the optimization of data points adopted in ECHAN. The points of A - D are experimental data points. $d$ is a maximum distance (from A to $\mathrm{E}$ ) allowed to next point, which is variable by the user. $\theta$ is a user-setting angle to reduce the interference of noise.

\section{2) Edit menu}

Figure 4 shows a "Special Copy" form module displayed by [Edit] - [Special copy]. The user can not only reduce the points of a data set but also convert the y-scale for exporting to the windows clipboard with this module. Figure 5 shows the illustration of a reduction algorithm. In the figure, the points of A to D express part of the experimental data. $d$ is the maximum distance allowed as a next point. To maintain the characteristic of the data, the points are selected as follows: After the aspect ratio of an electrochemical data set is adjusted to 1, first (Fig-

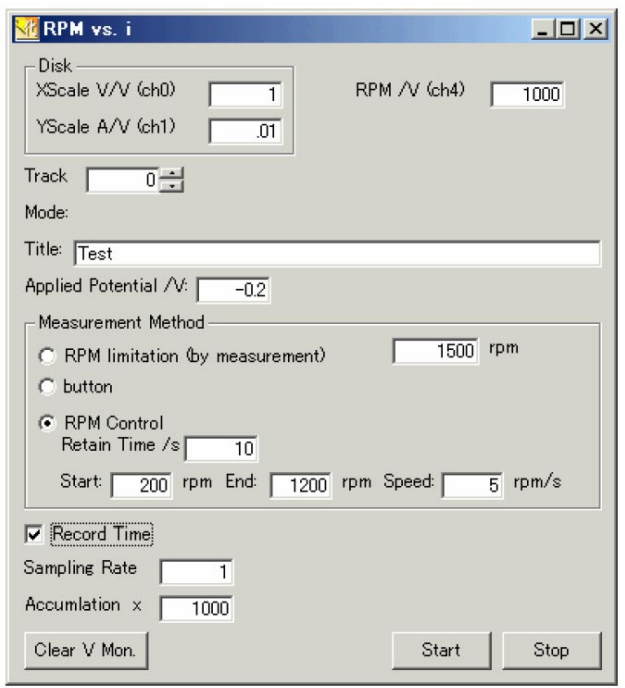

Figure 6. Form module of rotating speed vs. current measurement.

ure 5, A) and second point (Figure 5, B) are adopted as a yardstick and as points for exporting to the clipboard. If the third point $\mathrm{C}$ is satisfied with a function of an angle $(\theta)$ and a distance $(d)$ (Figure 5, hatched region), the point $C$ is skipped [9], and the next point $\mathrm{D}$ is examined in the same way. If the position of C is located to that of C', which is out of the hatched area, the point $C^{\prime}$ is adopted as a point for exporting to the clipboard, and the point $\mathrm{B}$ and the point $C^{\prime}$ are adopted as a new yardstick. The number of the data points decreases with increasing $d$ value, and large $\theta$ enables to skip scattered points. The user can confirm the reduced data points in a preview window (Figure $4,(1))$ as black points after clicking the [Go] button.

3) Measurement menu

In the program, the user select measurements from the menu of cyclic voltammetry, rotating ring-disk voltammetry, potential step chronoamperometry, measurement of current vs. rotating speed at a fixed potential, and multipotentiostat measurement either hydrostatically or hydrodymanically. Figure 6 shows a form module of rotating speeds vs. current measurement at a fixed applied potential. The user can use not only the manual settings of rotating speed but also a sweep mode for the rotation speed that is conducted by a D/A output of PCI9112, connected to a speed controller.

\section{4) Calculation menu}

Data sets obtained by measurements can be processed for noise elimination by a FFT low pass filter, for smoothing by the simple moving average or the Savitzky-Golay method [10] and for data transformation (addition, subtraction and multiplication) between two data sets.

5) Analysis menu 
The user can analyze data sets by means of the Koutecky-Levich equation, the Levich equation, the Cottrell's equation, the coulomb number calculation, the Tafel equation and the electron number calculation concerned with oxygen reduction reaction [11].

\section{6) Tools Menu}

Successive electrochemical measurements can be performed using an original macro language when a GPIB-based function generator is used. A program written in the macro language can be executable on "ECHAN" which is equipped with a simple macro editor. "ECHAN" interprets the program in a sequential order. Since the templates for the measurements are equipped in the macro editor, the users can input a sequential program very easily. List 1 shows a sample program list of the macro language. In the sample program, after the program finishes measurement of a cyclic voltammogram at hydrostatic condition and then a rotating ringdisk voltammogram measurement at a rotation speed of $300 \mathrm{rpm}$, it sends a message to a specific e-mail address.

List 1. Sample program list of the macro language.

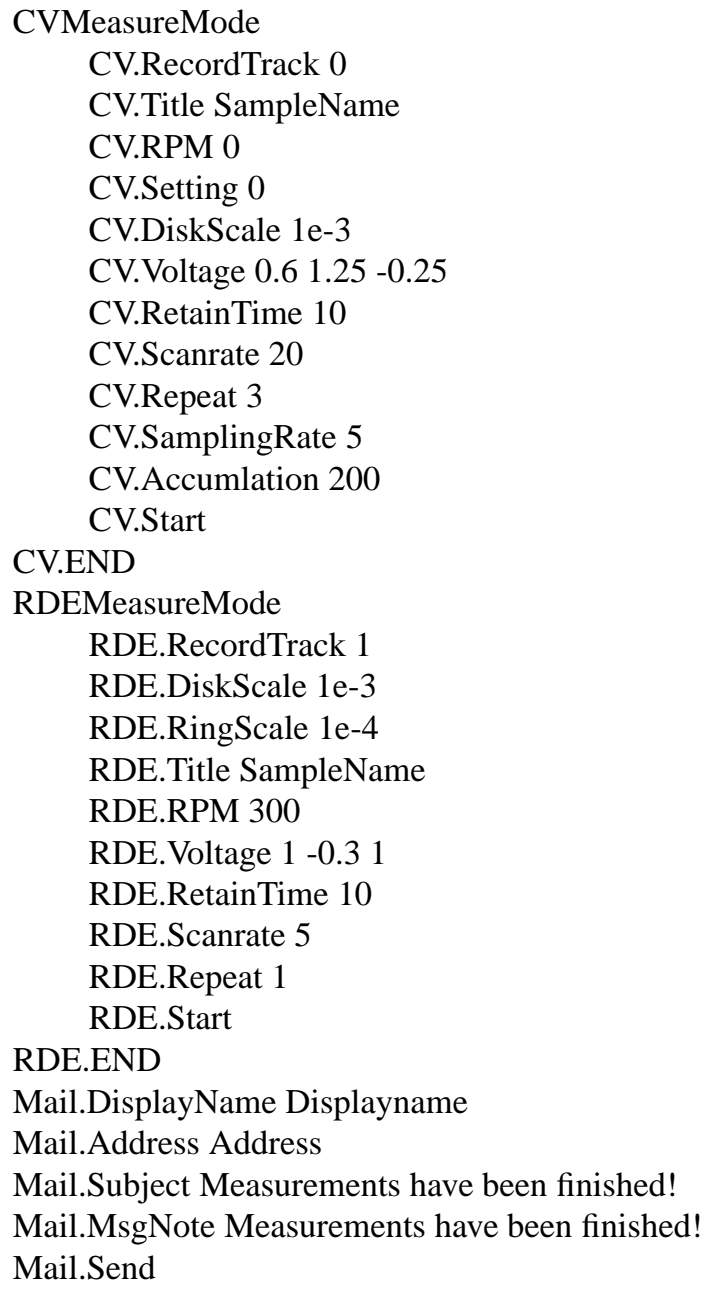

\section{Conclusion}

An open-source electrochemical measurement system called "ECHAN" has been developed with Visual Basic. A user can perform various electrochemical measurements automatically with an original macro language when a GPIB-based function generator is used.

\section{Availability}

The "ECHAN" is distributed through a web site: http://www.vector.co.jp/vpack/browse/person/an034990.html.

\section{Agreements for using the pro- gram}

The "ECHAN" is GPL. We cannot be responsible for damages that you might suffer when using this program. You can remodel this program without our permission [12]. Please feel free to contact us, when you find bugs.

We thank Mr. Noriyuki Ueno for making the power control unit.

\section{References}

[1] M. E. Lippitsch, J. Pusterhofer, M. J. P. Leiner, O. S. Wolfbeis, Anal. Chim. Acta, 205, 1 (1988).

[2] M. Kaneko, T. Takekawa, T. Asakura, Makromol. Chem., Macromol. Symp., 59, 183 (1992).

[3] S. Lee, I. Okura, Anal. Sci., 13, 535 (1997).

[4] M.C. Chakravorti and G.V.B. Subrahmanyam, Coord. Chem. Rev., 135-136, 65 (1994).

[5] A. J. Downald, D. Pletcher, J. Electroanal. Chem., 206, 147 (1986).

[6] T. Okada, M. Gokita, M. Yuasa, and Isao Sekine, $J$. Electrochem. Soc., 145, 815 (1998).

[7] J. P. Collman, L. L. Chng, and D. A. Tyvoll, Inorg. Chem., 34, 1311 (1995).

[8] T. Okada, M. Yoshida, T. Hirose, K. Kasuga, T. Yu, M. Yuasa, I. Sekine, Electrochim. Acta, 45, 4419 (2000).

[9] The decaying curve from point $\mathrm{B}$ to point $\mathrm{E}$ is defined as $d(r-\theta)^{\mathrm{n}} / \theta^{\mathrm{n}}+x_{A B}$, where $r$ is a radian, and $x_{A B}$ is a $\left|x_{B}-x_{A}\right|$. 
[10] A. Savitzky, M. J. E. Golay, Anal. Chem., 36, 1627 (1964).

[11] A. J. Bard and L. R. Faulkner, Electrochemical Methods, Fundamentals and Applications, Second
Edition, John Wiley and Sons, New York, NY (2001).

[12] The development kit attached to an A/D board is needed for compiling the program.

\title{
連続自動測定マクロ言語を装備し た オープンソース電気化学測定システムの開発
}

\author{
城石 英伸 ${ }^{\mathrm{a} *}$, 岡田 達弘 $\mathrm{b}$
}
$a$ 産業技術総合研究所環境調和技術研究部門 (NEDO フェロー), $=305-8565$ 茨城県つくば市東 1-1-1 中央第 5 $\mathrm{b}$ 産業技術総合研究所環境調和技術研究部門, $\overline{7} 305-8565$ 茨城県つくば市東 1-1-1 中央第 5 *e-mail: cpx26485@mopera.ne.jp

連続自動測定のためのマクロ言語を装備したオープンソースの電気化学測定システム (ElectroCHemicalANalyzer, ECHAN) を作成した。この測定システムは，サイクリックボルタモグラ ム, 回転リング-ディスク電極測定，ポテンシャルステップ測定ならびに定電位での電流値の回転数依 存性を自動的に連続して測定することができる。データベース的機能として測定データのキーワード・ 測定条件検索を装備した。また，データ演算機能として FFT(高速フーリエ変換)によるローパスフィ ルタ, 単純移動平均と Savitzky-Golay 法による平滑化 , 測定データ (トラック) 間の演算を備える。更 に, データ解析機能として, Koutecky-Levich 解析, Levich 解析, 酸素還元反心における反応電子数解 析, Cottrell 式による解析, Coulomb 数計算, Tafel 解析機能を備える。

また，データサンプリング部は A/D ボードベースであり，従来のレコーダーベースの電気 化学測定装置と容易に組み合わせることができるほか，才ープンソースであるため，任意の 装置にあわせてユーザーが自由にプログラムを書き換えることができる。このプログラムは http://www.vector.co.jp/vpack/browse/person/an034990.html にて公開する。

キーワード : 電気化学測定システム, ECHAN, 連続自動測定, オープンソース, 酸素還元,

触媒スクリーニング 